\title{
ADRENAL DISCHARGE PRODUCED BY DRLGS INJECTED INTO THE ADRENAL
}

\author{
B. A. HOUSSAY ANd E. A. MOLINELII \\ From the Instilute of Physiology, Faculty of Medicine, Buenos Aires \\ Received for publication March 5, 1926
}

When studying the effects of nicotin on adrenal secretion it was found that the injection of this drug into the adrenal gland produced a marked increase of the epinephrin secretion. In this paper the effects of several other drugs have been studied by the same method.

Previous work. In the literature no reference has been found on the effects produced by injecting drugs into the adrenal tissue. Perfusion experiments, a technique closely related to direct injection into the tissue, have been made repeatedly to study adrenal secretion or the vascular reactions of the gland. Masuda (1921) perfused the rabbit's adrenal with normal saline. Schkawera and Kusnetzow (1923) used bovine adrenals maintained at $38^{\circ} \mathrm{C}$. and perfused the arteries with Locke's solution. Kudrjazew (1924) and Nikolaeff (1924) worked with the same method. Takenaga (1924) used Tyrode's fluid in perfusion experiments on the dog's adrenal.

The vascular reactions of the adrenals have been studied in detail. The adrenal veins have a thick muscular coat, their structure, innervation, and their physiological and pathological reactions have been described by Peindarie (1920), Dubreuil (1920), Maresch (1921), Sheppard (1922) and Kashiwagi (1922).

Adrenalin injected into the circulation reduces the volume of the dog's adrenal, as it does that of other abdominal viscera (plethysmographic method in the intact animal, Hallion, 1920). Perfusion experiments with Tyrode's fluid showed that a concentration of $1: 10,000,000$ adrenalin constricted the dog's adrenal (Takenaga, 1924). The volume of the rabbit's adrenal diminishes when perfused with an adrenalin solution of $1: 10,000$, in normal saline, in some cases a concentration of $1: 50,000$ was effective (Masuda, 1921). The bovine surviving adrenal does not react in this way to the presence of adrenalin in the perfusing fluid; sometimes only a very slight constriction was observed, at others a dilatation was recorded (Schkawera and Kusnetzow, 1923). Wertheimer (1922) while studying the capillaries of the frog's adrenal in situ saw them dilate when adrenalin was injected into the circulation. 
Concentrated salt and concentrated hydrochloric acid solutions dilate the vessels of the gland; dilute solutions of the same substances produce constriction. Alkaline solutions and cholin also produce constriction. Cocain, chloral hydrate and amyl nitrite are vasodilators. These results were obtained by perfusing the rabbit's surviving adrenal (Masuda).

The blood vessels of the bovine surviving adrenal are less sensitive to vasoconstrictors (adrenalin, histamin, barium chloride, strophanthin and nicotin) than are other vascular regions of the same animal. Conversely, they dilate more easily when caffein is perfused (Schkawera and Kusnetzow).

Nikolaeff (1924) found that phenol and coniin are weak vasoconstrictors; pyrocatechin and tyramin also constrict but produce a secondary dilatation. Narcotics of the fatty series are vasodilators; alcohols have a dilating effect in direct proportion to their molecular weight; casein is a dilator; peptone has only a very slight dilating power. Tyrosin and its peptids have no effect on the adrenal's blood vessels.

The vessels of a dog's surviving adrenal, perfused with Tyrode's fluid, constrict when epinephrin, histamin or cholin are added even in concentrations of 1:10,000,000 (Takenaga, 1924).

Krichel, quoted by Eichholtz (1923), found no change in the adrenal veins in the presence of nicotin, atropin, strychnin, adrenalin and the bases of quaternary ammonias.

Locke's fluid is a vasoconstrictor after it has passed through the adrenal (Schkawera and Kusnetzow, 1923; Kudrjazew, 1924). This is not due to the presence of epinephrin extracted from the gland, as this property persists after heating, treatment with alkali, and prolonged standing. The pink color given by epinephrin is not present. If epinephrin is added to the fluid, the tests mentioned above cause it to deteriorate so that the presence of protective substances can not be invoked to explain a possible persistence of adrenalin. The constricting power of the fluid is equivalent to that of an adrenalin solution of from $1: 20,000$ to $1: 100,000$. In the cortex a muscarin-like substance was found. The constricting substance is more active at $38^{\circ}$ to $40^{\circ} \mathrm{C}$. than at $9^{\circ} \mathrm{C}$. It is more abundant in the anterior part of the gland, and is not extracted by washing out but is secreted into the fluid, because it can be obtained for several days. By this method, moreover, a greater quantity of epinephrin is obtained than by simple extraction. Nicotin increases this secretion 400 to 600 per cent with no preliminary diminution. Eserin also increases the secretion, but not so intensely (150 per cent); pilocarpin does not affect it. Schkawera and Ssentjurin (1925) found that fluid which had perfused the testicle increased the secretion. Chloroform and chloral hydrate have no effect in dilute solutions, but in concentrations of from 1:200 to 1:500 they first increase and then diminish the secretion. Peptone, casein, ethyl alcohol 
(0.1 per cent), amyl alcohol, acetone, nicotin and tyramin increase the secretion; tyrosin is inactive but one of its peptids increases it slightly; methyl alcohol diminishes the secretion. Tyramin does not alter the chromaphil reaction of the adrenal medulla.

The perfusion of the isolated bovine adrenal with concentrated solutions of sodium carbonate (1:10,000 or more) increases the epinephrin secretion. More dilute solutions $(1: 100,000)$ are less effective. Concentrated solutions of lactic acid increase the secretion. The maximum is obtained when the $\mathrm{pH}$ of the perfusion fluid is 7.32. Concentrations of $1: 3,000$ lactic acid inhibit secretion; lower concentrations $(1: 4,000)$ are inactive.

Experiments. Dogs anesthetized with chloralose $(0.10 \mathrm{gm}$. per $\mathrm{kgm}$. given intravenously) were used in all the experiments. Tournade and Chabrol's transfusion technique was followed. The donor's blood pressure, the recipient's blood pressure, and the rate of the denervated heart were recorded.

The donor's left adrenal was well separated from the surrounding tissues along its external border. A forceps holding the connective tissue near the gland served to maintain it fixed while a fine needle was inserted in its external border and directed towards the center. The fluid (generally 0.1 cc., exceptionally 0.2 cc.) was then injected from a very exactly calibrated syringe. The needle was rapidly taken out.

The discharge obtained was more marked when the injection was made either immediately above or below the lumbo-adrenal vein. No injections were made below a point $3 \mathrm{~mm}$. distant from the lower extremity of the gland. It is inadvisable to make more than four or five injections in one gland since this adds to the sources of error. One such source that has been observed is the discharge produced by an inactive substance when injected in the same place previously used for the injection of an active drug. The amount discharged is generally the same in two consecutive injections of equal doses of a drug. Sometimes, however, different reactions are obtained under these conditions, due, principally, to the different locations of the two injections; e.g., one being made near the center, the other near the inferior extremity of the gland. The latter produces a smaller discharge. As is to be expected, all animals are not equally sensitive and their reactions vary accordingly.

Stewart (1912), Popielski (1913), Stewart, Rogoff and Gibson (1916) and Gautrelet (1923) have proved that massage of the adrenal produces an epinephrin discharge, a fact that we have confirmed. Our results might, therefore, be due to the handling of the gland and not to the action of the drugs. This argument may be disregarded because we have repeatedly observed that when care is taken in handling the gland and in introducing the needle, the epinephrin discharge is not sufficient to modify the blood pressure and the rate of the denervated heart of the recipient. Control 
TABLE 1

\begin{tabular}{|c|c|c|c|c|c|c|c|c|}
\hline \multirow{2}{*}{$\begin{array}{l}\text { DATE, } \\
1925\end{array}$} & \multicolumn{2}{|c|}{ WEIGHT } & \multirow{2}{*}{ DRUA INJECTED } & \multirow{2}{*}{\multicolumn{2}{|c|}{ AMOUNT }} & \multicolumn{2}{|c|}{$\begin{array}{l}\text { RISE IN BLOOD } \\
\text { PRESSURE }\end{array}$} & \multirow{2}{*}{$\begin{array}{l}\text { INCREASE } \\
\text { IN HEART } \\
\text { RATE OF } \\
\text { RE- } \\
\text { CIPIENT }\end{array}$} \\
\hline & Donor & $\begin{array}{c}\text { Re- } \\
\text { cipient }\end{array}$ & & & & Donor & $\begin{array}{c}\text { Re- } \\
\text { cipient }\end{array}$ & \\
\hline & $\mathrm{kgm}$. & $\dot{k g m}$. & & & & $m m . \mathrm{Hg}$ & $m m . H g$ & $\begin{array}{c}\text { beats } \\
\text { per min. }\end{array}$ \\
\hline $7 / 20$ & 23.5 & 11.0 & Nicotin & 0.00001 & mgm. & 0 & 0 & 0 \\
\hline $7 / 20$ & 23.5 & 11.0 & Nicotin & 0.0001 & mgm. & 0 & 52 & 40 \\
\hline $6 / 5$ & 23.0 & 9.3 & Nicotin & 0.15 & mgm. & 0 & 90 & 64 \\
\hline${ }^{*} 9 / 15$ & 21.5 & 14.0 & Nicotin & 0.05 & mgm. & 0 & 62 & 44 \\
\hline $6 / 30$ & 31.0 & 29.0 & Eserin & 0.0002 & mgm. & 0 & 0 & 4 \\
\hline $6 / 30$ & 31.0 & 29.0 & Eserin & 0.002 & mgm. & 0 & 110 & 22 \\
\hline $6 / 20$ & 30.0 & 9.5 & Eserin & 0.01 & mgm. & 0 & 130 & 36 \\
\hline $6 / 17$ & 30.0 & 11.0 & Eserin & 0.1 & mgm. & 0 & 60 & 48 \\
\hline$* 9 / 15$ & 21.5 & 14.0 & Eserin & 0.01 & mgm. & 0 & 0 & 0 \\
\hline$* 9 / 15$ & 21.5 & 14.0 & Eserin & 0.1 & mgm. & 0 & 0 & 0 \\
\hline $7 / 28$ & 29.5 & 10.5 & Hydrastinin & 0.001 & mgm. & 0 & 76 & 30 \\
\hline $7 / 28$ & 29.5 & 10.5 & Hydrastinin & 0.1 & mgm. & 0 & 74 & 28 \\
\hline $9 / 8$ & 29.0 & 13.0 & Morphia & 0.001 & mgm. & 0 & 0 & 0 \\
\hline $9 / 12$ & 16.0 & 14.5 & Morphia & 0.001 & mgm. & 0 & 0 & 0 \\
\hline $9 / 8$ & 29.0 & 13.0 & Morphia & 0.01 & mgm. & 0 & 80 & 12 \\
\hline $9 / 12$ & 16.0 & 14.5 & Morphia & 0.01 & mgm. & 0 & 20 & 4 \\
\hline $7 / 28$ & 29.5 & 10.5 & Morphia & 0.1 & mgm. & 0 & 110 & 72 \\
\hline $6 / 30$ & 31.0 & 29.0 & Adrenalin & 0.025 & mgm. & 0 & 0 & 2 \\
\hline $7 / 20$ & 23.5 & 11.0 & Adrenalin & 0.025 & mgm. & 0 & 74 & 58 \\
\hline $7 / 21$ & 19.5 & 11.5 & Adrenalin & 0.025 & mgm. & 0 & 94 & 78 \\
\hline $6 / 20$ & 30.0 & 9.5 & Arecholin & 0.01 & mgm. & 0 & 0 & 0 \\
\hline $6 / 19$ & 30.0 & 9.5 & Arecholin & 0.05 & mgm. & 0 & 0 & 0 \\
\hline $6 / 17$ & 30.0 & 11.0 & Arecholin & 0.1 & mgm. & 0 & 68 & 22 \\
\hline $7 / 21$ & 19.5 & 11.5 & Acetylcholin & 0.001 & mgm. & 0 & 0 & 0 \\
\hline $7 / 21$ & 19.5 & 11.5 & Acetylcholin & 0.1 & mgm. & 0 & 80 & 82 \\
\hline $7 / 28$ & 29.5 & 10.5 & Quinin & 0.1 & mgm. & 0 & 48 & 0 \\
\hline$* 7 / 25$ & 19.0 & 11.5 & Quinin & 0.1 & mgm. & 0 & 0 & 0 \\
\hline$* 7 / 25$ & 19.0 & 11.5 & Quinin & 0.01 & mgm. & 0 & 0 & 0 \\
\hline$* 7 / 24$ & 17.5 & 15.5 & Atropin & 0.001 & mgm. & 0 & 21 & 6 \\
\hline$* 7 / 24$ & 17.5 & 15.5 & Atropin & 0.01 & mgm. & 0 & 0 & 0 \\
\hline$* 7 / 24$ & 17.5 & 15.5 & Atropin & 0.1 & mgm. & 0 & 0 & 0 \\
\hline$* 7 / 24$ & 17.5 & 15.5 & Atropin & 0.1 & mgm. & 0 & 32 & 8 \\
\hline $9 / 18$ & 24.0 & 11.5 & Atropin & 0.01 & mgm. & 0 & 0 & 0 \\
\hline $9 / 18$ & 24.0 & 11.5 & Atropin & 0.1 & mgm. & 0 & 0 & 0 \\
\hline $6 / 17$ & 30.0 & 11.0 & Strychnin & 0.1 & mgm. & 0 & 28 & 40 \\
\hline $7 / 28$ & 29.5 & 10.5 & Strychnin & 0.1 & mgm. & 0 & 10 & 4 \\
\hline$* 7 / 25$ & 19.0 & 11.5 & Strychnin & 0.1 & $\mathrm{mgm}$. & 0 & 0 & 0 \\
\hline $7 / 31$ & 17.0 & 15.5 & Peptone & 0.1 & mgm. & 0 & 10 & 8 \\
\hline $7 / 31$ & 17.0 & 15.5 & Veratrin & 0.1 & mgm. & 0 & 14 & 13 \\
\hline $7 / 28$ & 29.5 & 10.5 & Picrotoxin & 0.1 & mgm. & 0 & 12 & 4 \\
\hline $7 / 24$ & 17.5 & 15.5 & Pilocarpin & 0.001 & mgm. & 0 & 4 & 4 \\
\hline $7 / 21$ & 19.5 & 11.5 & Pilocarpin & 0.01 & mgm. & 0 & 22 & 3.4 \\
\hline $7 / 24$ & 17.5 & 15.5 & Pilocarpin & 0.1 & mgm. & 0 & 0 & 6 \\
\hline
\end{tabular}


TABLE 1-Concluded

\begin{tabular}{|c|c|c|c|c|c|c|c|c|}
\hline \multirow{2}{*}{$\begin{array}{l}\text { D.ATE, } \\
1925\end{array}$} & \multicolumn{2}{|c|}{ WEIGHT } & \multirow{2}{*}{ DRUG INJECTED } & \multirow{2}{*}{\multicolumn{2}{|c|}{ AMOUNT }} & \multicolumn{2}{|c|}{$\begin{array}{l}\text { RISE IN BLOOD } \\
\text { PREGSURE }\end{array}$} & \multirow{2}{*}{$\begin{array}{l}\text { INCREASE } \\
\text { XN HEART } \\
\text { RATE OF } \\
\text { RE- } \\
\text { CIPIENT }\end{array}$} \\
\hline & Donor & $\begin{array}{l}\text { Re- } \\
\text { cipient }\end{array}$ & & & & Donor & $\underset{\text { cipient }}{\text { Ro- }}$ & \\
\hline & kgm. & $\mathrm{kgm}$. & & & & $m m . H g$ & $m m . H_{\theta}$ & $\begin{array}{l}\text { beats } \\
\text { per min. }\end{array}$ \\
\hline $7 / 24$ & 17.5 & 15.5 & Pilocarpin & 0.1 & mgm. & 0 & 0 & 2 \\
\hline $7 / 28$ & 29.5 & 10.5 & L. Alternat. & 0.1 & mgm. & 0 & 10 & 4 \\
\hline $7 / 31$ & 17.0 & 15.5 & Cobra venom & 0.1 & $\mathrm{mgm}$. & 0 & 6 & 4 \\
\hline $7 / 28$ & 29.5 & 10.5 & Strophanthin & 0.1 & mgm. & 0 & 10 & 0 \\
\hline $7 / 25$ & 19.0 & 11.5 & Strophanthin & 0.001 & mgm. & 0 & 0 & 0 \\
\hline $7 / 25$ & 19.0 & 11.5 & Strophanthin & 0.01 & $\mathrm{mgm}$. & 0 & 0 & 0 \\
\hline $7 / 25$ & 19.0 & 11.5 & Strophanthin & 0.1 & $\mathrm{mgm}$. & 0 & 0 & 0 \\
\hline $9 / 8$ & 29.0 & 13.0 & $\mathrm{HCl} 0.01 \mathrm{~N}$ & $0.1 \mathrm{cc}$ & & 0 & 70 & 20 \\
\hline $7 / 24$ & 17.5 & 15.5 & $\mathrm{HCl} 0.01 \mathrm{~N}$ & $0.1 \mathrm{cc}$ & & 0 & $\mathbf{0}$ & $\mathbf{0}$ \\
\hline $9 / 12$ & 16.0 & 14.5 & $\mathrm{HCl} 0.001 \mathrm{~N}$ & $0.1 \mathrm{ec}$ & & 0 & 0 & 0 \\
\hline $7 / 24$ & 17.5 & 15.5 & $\mathrm{HCl} 0.001 \mathrm{~N}$ & $0.1 \mathrm{cc}$ & & 0 & 0 & 0 \\
\hline $9 / 8$ & 29.0 & 13.0 & $\mathrm{Na}(\mathrm{OH}) 0.01 \mathrm{~N}$ & $0.1 \mathrm{cc}$ & & 0 & 70 & 20 \\
\hline $9 / 12$ & 16.0 & 14.5 & $\mathrm{Na}(\mathrm{OH}) 0.001 \mathrm{~N}$ & $0.1 \mathrm{cc}$ & & 0 & 0 & 0 \\
\hline $7 / 31$ & 17.0 & 15.5 & Ergamin & $0.1 \mathrm{~m}$ & & 0 & 0 & 0 \\
\hline$\dagger 7 / 17$ & 30.0 & 11.0 & Scorpion venom & $0.1 \mathrm{cc}$ & & 0 & 0 & 0 \\
\hline$\dagger 9 / 18$ & 11.5 & & Scorpion venom & $i_{1}^{1} \overline{0} \mathrm{gl}$ & & 0 & 0 & 0 \\
\hline
\end{tabular}

Note: The following salts were used: Eserin salicylate, morphin chlorhydrate, quinin chlorhydrate, atropin sulphate, strychnin nitrate, pilocarpin nitrate, histamin phosphate. The other drugs used were bases.

* The left splanchnic was severed.

† One gland in $20 \mathrm{cc}$. normal saline.

experiments were also performed in which $0.1 \mathrm{cc}$. and $0.15 \mathrm{cc}$. of 0.8 per cent sodium chloride solutions were injected in exactly the same way as the drugs. In no case ( 8 experiments) did we observe a rise of blood pressure or an increase in heart rate in the recipient.

Sometimes when an inactive drug or sodium chloride solution was given, a slight fall was seen in the recipient's blood pressure (fig. 3). This might be due to a small adrenal discharge, but it was never taken into account.

Negative results were also obtained with $0.1 \mathrm{cc}$. (four experiments) and $0.15 \mathrm{cc}$. (two experiments) normal horse serum (fig. 1).

Nicotin is the most potent among the active drugs; $0.0001 \mathrm{mgm}$. gives a marked discharge, $0.00001 \mathrm{mgm}$. is not effective. The following drugs also give positive results; eserin (fig. 1), hydrastinin (fig. 2), morphia (fig. 2), pilocarpin (fig. 3) and adrenalin (fig. 4).

These results are somewhat surprising because they disagree with results obtained by intravenous injection of the same substances that will be published later. Intravenously given, eserin produces a discharge, hydrastinin and morphia have an inconstant effect, and adrenalin is inactive.

Other drugs produce a discharge when given in large doses; e.g., 0.1 

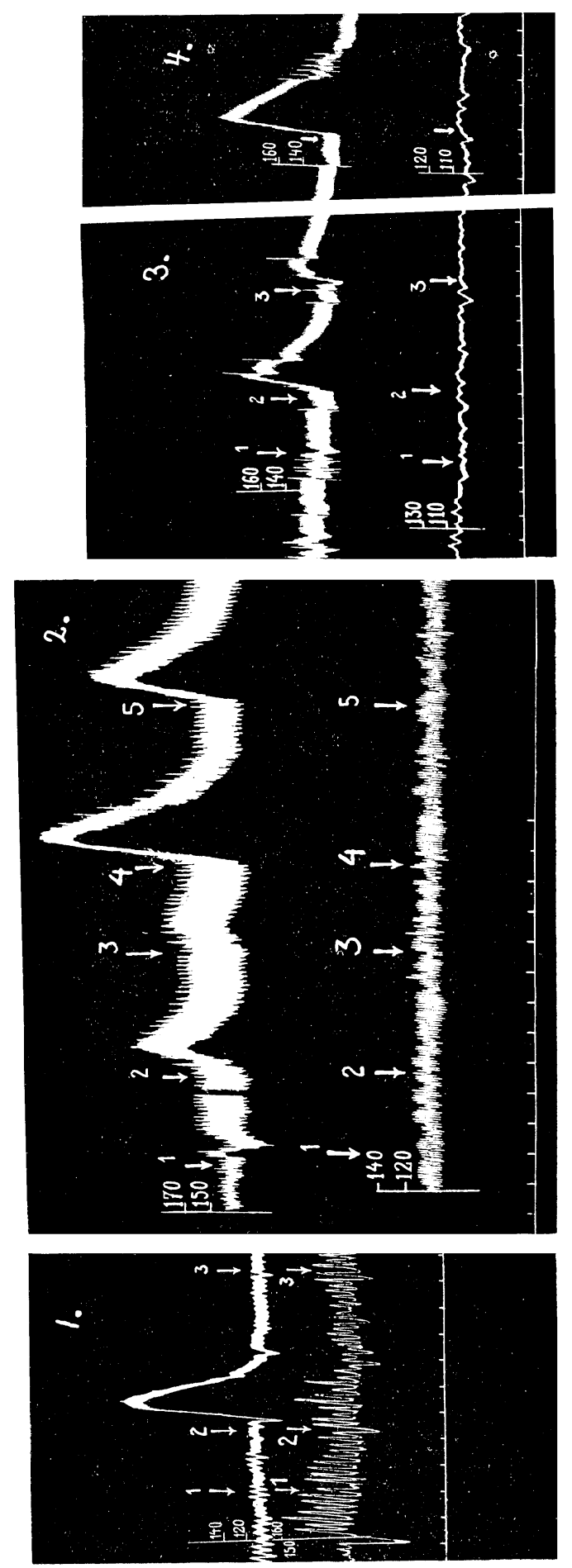

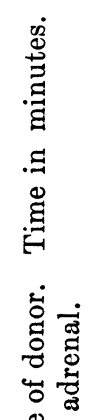

定

卺

\&.

疋.

$\because$

पั0

总

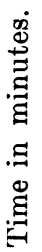

.

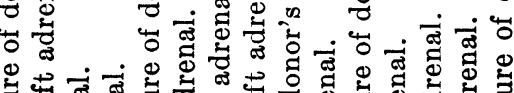

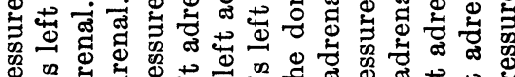

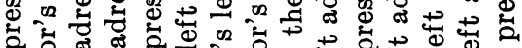

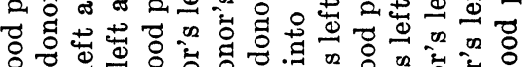

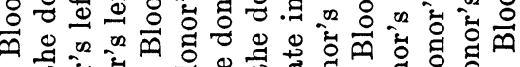

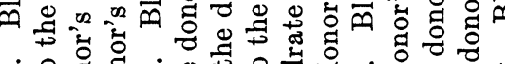

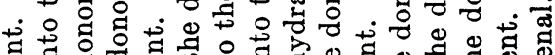

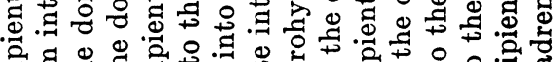

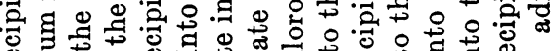

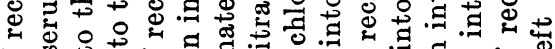

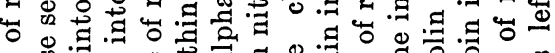
o

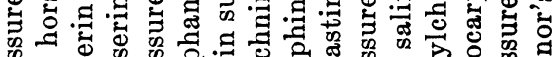

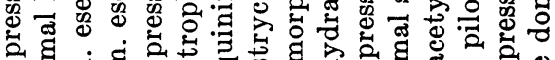

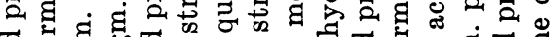

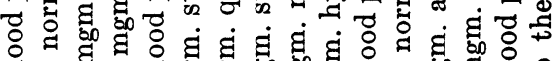

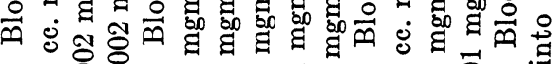
-1 ม ज्ञ ภิ

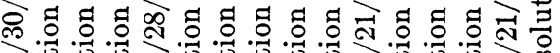

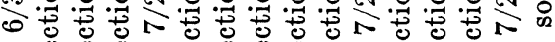

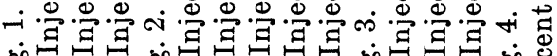

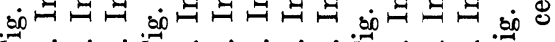

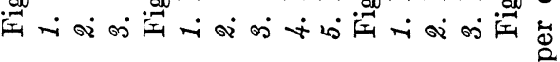


mgm. arecholin, acetylcholin (fig. 3), quinin (fig. 2), atropin and strychnin (fig. 2). The discharge produced by this dose of strychnin is slight and is a contrast to the marked results obtained when it is injected into the circulation where it can influence the central nervous system.

Sodium hydrate and hydrochloric acid solutions are active when given in certain concentration $(0.01 \mathrm{~N})$; more dilute solutions $(0.001 \mathrm{~N})$ are inactive.

Only slight discharges were obtained with $0.1 \mathrm{mgm}$. Witte's peptone, strophanthin (fig. 2), veratrin, picrotoxin and the venoms of Lachesis alternatus and Naja tripudians. Ergamin and the venom of a scorpion (Butus quinquestriatus) are inactive.

Sympathico-mimetic (adrenalin, nicotin) and parasympathico-mimetic (nicotin, eserin, arecholin) drugs are equally active. Their effects might be attributed to a local irritative and nonspecific action, but it has been seen that ergamin, veratrin and snake venoms-substances that have a potent local action - have little or no effect when injected directly into the adrenal.

Reflex action can also be disregarded, since positive results were obtained with nicotin and eserin in denervated glands. The amounts discharged were smaller, due possibly to the almost total supression of secretion in denervated glands.

The method is useful in the study of the local action of substances on the gland, but it does not permit any inference as to the action of a drug given intravenously because the effects are not always parallel. In some cases, as with nicotin, the effects are identical; in others, as with strychnin, they are not.

Although at first sight the perfusion of surviving glands appears to be a better method, it produces greater alteration in the normal reactions of the gland; e.g., stimulation of the splanchnic does not greatly increase the adrenal secretion of surviving glands (Kudrjazew, 1924), whereas it increases markedly the secretion of glands perfused in situ. Possibly in the surviving gland some alteration may occur in the synapse (splanchnic nerve and medulli-adrenal cell).

\section{SUMMARY}

1. Injection into the adrenal gland of 0.1 cc. normal saline solution or normal horse serum does not produce an adrenal discharge.

2. Marked adrenal discharge is produced by the injection of nicotin, eserin, hydrastinin, adrenalin, pilocarpin and morphia.

3. Arecholin, acetylcholin, quinin, atropin and strychnin produce a discharge when injected in large doses.

4. Only slight discharges were produced by Witte's peptone, veratrin, picrotoxin and the venoms of Lachesis alternatus and Naja tripudians. 
5. Negative results were obtained with strophanthin, ergamin and the venom of Butus quinquestriatus.

\section{BIBLIOGRAPHY}

Eichнoltz, F. 1923. Arch. f. Exper. Path. u. Pharm., xcix, 172.

Dubreuil, G. 1920. C. R. Soc. Biol., lxxxiii, 1096.

Gautrelet, J. 1923. C. R. Soc. Biol., Ixxxviii, 566.

Hallion, L. 1920. Congrès de Physiologie, Paris, Juillet.

Kashiwagi, S. 1922. Trans. Jap. Pathol. Soc., xii, 154. Abstr.

Kudruazew, N. N. 1924. Zeitschr. f. d. gesammt. exper. Med., xli, 114.

Maresch, R. 1921. Wien. Klin. Wochnschr., xxxiv, 44.

Masuda, T. 1921. Acta Scholae Med. Univ. imp. Kyoto, v, 57, ref. in Ber. ges. Physiol. u. Exper. Pharm., 1923, xvi, 362.

Nikolaeff, M. P. 1924. Zeitschr. f. d. gesammt. exper. Med., xlii, 227.

Nikolaeff, M. P. 1925. Zeitschr. f. d. gesammt. exper. Med., xliv, 418.

Peindarie, J. 1920. C. R. Soc. Biol., Ixxxiii, 958.

Popielski, L. 1913. Zentralbl. f. Physiol., xxvii, 479.

Schkawera, G. L. and A. I. Kusnetzow. 1923. Zeitschr. f. d. gesammt. exper. Med., xxxviii, 37.

Schkawera, G. L. ANd B. S. Ssentudrin. 1925. Zeitschr. f. d. gesammt. exper. Med., xliv, 748.

Sheppard. 1922. Anat. Rec., xxiii, 37.

Stewart, G. N. 1912. Journ. Exper. Med., xv, 555-cit. Stewart, Rogoff and Gibson.

Stewart, G. N., J. M. Rogoff and F. S. Gibson. 1916. Journ. Pharm. Exper. Therap., viii, 205, 245.

Takenaga. 1924. Pflüger's Arch., ccv, 285.

Wertheimer, E. 1922. Pflüger's Arch., excvi, 412. 